This item was submitted to Loughborough's Research Repository by the author.

Items in Figshare are protected by copyright, with all rights reserved, unless otherwise indicated.

\title{
Royal Navy gunners in the French Revolutionary and Napoleonic Wars
}

\section{PLEASE CITE THE PUBLISHED VERSION}

http://dx.doi.org/10.1080/00253359.2009.10657104

\section{PUBLISHER}

(c) Society for Nautical Research

\section{VERSION}

VoR (Version of Record)

\section{PUBLISHER STATEMENT}

This work is made available according to the conditions of the Creative Commons Attribution-NonCommercialNoDerivatives 4.0 International (CC BY-NC-ND 4.0) licence. Full details of this licence are available at: https://creativecommons.org/licenses/by-nc-nd/4.0/

\section{LICENCE}

CC BY-NC-ND 4.0

\section{REPOSITORY RECORD}

Cole, Gareth J.. 2019. "Royal Navy Gunners in the French Revolutionary and Napoleonic Wars". figshare. https://hdl.handle.net/2134/16966. 


\title{
ROYAL NAVY GUNNERS IN THE FRENCH REVOLUTIONARY AND NAPLOEONIC WARS ${ }^{1}$
}

\author{
By Gareth Cole
}

$\mathrm{R}$

oyal Navy gunners comprised part of the class of warrant officers on board warships. They were appointed by the Navy Board but responsible for the ordnance stores on their ship. As warrant officers they were permanently attached to the ship. N.A.M. Rodger, in The Wooden World: An anatomy of the Georgian Navy, describes the various standing officers of the sailing navy. He states that the gunner 'usually had no pretensions to gentility', but adds, 'there were exceptions'. 'The same author states elsewhere that 'gunners were almost always former working petty officers and common seamen'. ${ }^{3}$ A number of contemporary publications believed that the gunner's duties were easier than will be described below. In Advice to the Officers of the British Navy printed in 1785, the author writes of the gunner's duties that:

you have nothing to do but to see the powder carefully handed up, and when all is over, the magazine put to rights and the guns duly secured. ${ }^{4}$

The anonymous author was referring to times of action but he neglects to mention any of the accounting and numerous other jobs that the gunner had to complete during any commission and which will be discussed in this article. The same author states that in foreign navies, particularly the French, the post 'is filled by persons well skilled in the Science of gunnery, and the arts that have a relation to it'. ${ }^{5}$ Another work, published at the height of the American War of Independence in 1779 , is scathing in its criticisms of gunners accusing them of defrauding the nation and being lazy. ${ }^{6}$ As will be shown, there were a number of suspicions that gunners were being fraudulent by skimping on the amount of powder fired in salutes. This meant that powder they had left over at the end of a commission could be sold on the black market. However, their accounts would still be correct because they would show the amount of powder that was supposed to have been fired and the correct amount would be returned to the ordnance magazines. In publishing anonymously the author or authors are not able to be traced and it is possible that the author of each was a naval officer discontented with the prosecution of the war (1779) and the ultimate conclusion of the war (1785).

This article will examine how one became a gunner; the role of the gunner on board ship once he was warranted; how these responsibilities fitted in with the ordnance and naval aspects of warfare at sea; how the gunner prepared a ship for battle; and what accounts and papers the gunner needed to complete.

\section{BECOMING A GUNNER}

Since the duties were both substantial and important, a gunner was not simply appointed as such. In the 1790 edition of the Regulations and Instructions relating to 
His Majesty's service at sea: Established by His Majesty in Council, article 34 stated that:

No person shall be warranted as Gunner of any of His Majesty's Ships, or, if made Abroad, have his warrant confirmed, before he has passed an Examination through the Several Parts of Gunnery, touching his Qualifications to serve as a Gunner in His Majesty's Navy, before a Mathematical Master, and three able Gunners of the Navy, chosen by the Commissioner of the Navy residing at the Port, and produces a Certificate from them, that he is fitly qualified to serve in that Station.

Prospective gunners, thus, had to prove their competency at specified tasks. First, they had to prove that they were good seamen. This was essential because on smaller warships it was expected that the gunner stood watch. In 1807, John Brockinan's neglect of duty as officer of the watch was found to have been the cause of the loss of the Atalante sloop. ${ }^{8}$ Second, they had to prove that they knew about the use and exercise of the great guns: what the proportion of powder was for each piece of artillery; how to fill cannon cartridges; how to arrange them in magazines; how to fill musket cartridges; and the use of wads. Third, they had to provide their service certificates. Last, they had to demonstrate that they were literate and numerate. This latter requirement was important because of the amount of paperwork that it was necessary for the gunner to complete. These qualities were examined by three gunners and a 'mathematical master' who then signed the applicant off as qualified.'

Prior to becoming a gunner, George Jones had been a midshipman. This was not an unknown career progression. A selection of ten gunners and an examination of their passing certificates exemplify this fact. Two of the ten had no previous rank given while two had been midshipmen, two master's mates, one an acting gunner, one a captain's clerk, another a captain's coxswain and the final man a purser's steward. ${ }^{10}$ Table 1 shows further details found on their certificates:

Table 1: Details on gunners' passing certificates

\begin{tabular}{llll} 
Name & Date & Previous rank & Years at sea \\
Austin, John & $27 / 01 / 1794$ & N/A & $5+$ \\
Bishop, John & $21 / 10 / 1789$ & N/A & $11+$ \\
Blyth, James & $02 / 09 / 1790$ & Master's mate & 10 years, 4 months, 3 weeks and 3 days \\
Bignell, John & $12 / 03 / 1791$ & Captain's clerk & 8 years, 3 months and 5 days \\
Brown, Nicholas & $23 / 10 / 1792$ & Master's mate & 7 years, 1 week and 6 days \\
Willcock, Richard & $12 / 08 / 1783$ & Midshipman & 4 years, 12 months, 2 weeks and 3 days \\
Richmond, George & $27 / 12 / 1790$ & Acting gunner & 6 years, 9 months, 1 week and 6 days \\
Picvans, John & $14 / 03 / 1797$ & Captain's coxswain 4 years, 2 months and 4 days \\
Spence, William & $09 / 12 / 1784$ & Purser's steward & 4 years, 11 months, 3 weeks and 1 day \\
Smith, Robert & $02 / 10 / 1794$ & Midshipman & 6 years, 8 months, 3 weeks and 3 days \\
\hline
\end{tabular}

Source: The National Archives of England and Wales (hereafter, NA) NA ADM 6/127.

\section{COMMISSIONING A SHIP}

When a warship was commissioned stores of different natures were needed on board. Additionally, from time to time a ship would need to re-arm after expending stores. As far as effectiveness in battle was concerned ordnance stores were arguably the most 
important. These could range in size and weight from massive 32-pounder cannon to a small nail. Whatever the store, if it was supplied by an Ordnance gunwharf or magazine it became the gunner's responsibility as soon as he had signed for it.

Orders for storing a ship came directly from the Ordnance and Admiralty Boards in London. When the stores were delivered to ships the gunner entered the amounts received into his account book. ${ }^{11}$ It was important for the gunner to keep this book up to date. Gunners, and captains, only received their pay once the gunner's accounts had been passed by the Office of the Clerk of the Ordnance. Thus, this initial delivery needed to be checked thoroughly.

The gunnery notebook of William Rivers (perhaps best known for being the gunner on Victory at the Battle of Trafalgar) adds some interesting detail as to what the gunner had to do when the ship was commissioned..$^{12}$ As regards the accounts he states:

Before you go to sea you must go to the Gunwharf and Indent for your stores. They will give you a charge of all the Stores you have on board. ${ }^{13}$

He also warns gunners to 'mind your magazine is well Dry before you Put in your powder'. ${ }^{14}$ Whenever anything major was to be done, such as painting the carriages or bringing stores on board ship, Rivers states that application should be made to the commanding officer. ${ }^{15}$

\section{AT SEA}

In many ways the gunner's job was only just beginning once the stores were on board ship: William Rivers states that once the ordnance stores were on board the gunner was to 'ask the commanding Officer when you shall fill Powder for the Guns and the Number of Rounds' ${ }^{16}$ This was especially important in time of war when a ship could meet an enemy at any time after leaving port. On 17 August 1779, Ardent (64), Captain Boteler commanding, was captured by the combined Franco-Spanish fleet off Plymouth, having mistaken them for the British fleet after the private signal was made and answered. Boteler tried to make sail but was 'cut off on every quarter'; he thus brought to and engaged a French frigate. He soon surrendered after a number of other enemy warships came within range. ${ }^{17}$ In the court martial following her loss part of the evidence implied that a lack of gunner's stores in the right place contributed to her loss. Under questioning, Charles Paterson, her first lieutenant was asked: 'Was there any Hindrance to the action ... from the want of powder being filled'? He replied, 'Yes, there was; we waited for powder some time. ${ }^{18}$ Boteler, in his evidence, stated:

I had neither Time given me to exercise, make wads, or any other preparation necessary to make a proper defence against so sudden Attack of an Enemy. ${ }^{19}$

A seaman, John Burgess, agreed with his captain and first lieutenant by saying that not only was there a problem getting wads, powder and matches to the quarterdeck (presumably his station) but 24-pounder cartridges were brought on to the quarterdeck for the 9-pounders mounted there.$^{20}$ Having taken this evidence the members of the court martial then examined the gunner, Archibald Macintyre. He was asked how many rounds of powder he had filled. He answered, 'Twenty rounds [per gun]; that was Captain Boteler's order to me, and I complied with it. ${ }^{21}$ This supports Rivers's statement that the gunner was not allowed to fill cartridges without the 
permission of the captain. In fact, the Regulations and Instructions stated in article 5 that the gunner was not to 'fill cartridges . . . without the Captain's Directions'. ${ }^{22}$ Macintyre continued that there were ten rounds of wads ready because they had taken 'two wads to each charge'. ${ }^{23}$ The average rate of fire for warships at this time is difficult to assess and Boteler admitted that 400 of his men had not been to sea before and 'as such, knew nothing of the Use of a Gun', so his crew were going to be below average. ${ }^{24}$ R.J.B. Knight has estimated that during the Battle of Cape St Vincent Nelson's ship, Captain, fired a broadside every four and a half minutes. ${ }^{25}$ If we take one round every five minutes as a ballpark figure then it is clear that Ardent had enough ammunition for fifty minutes of action, even without Macintyre filling any more cartridges. As shown in the brief account above, no evidence in the court martial implies an extended action and, indeed, the court found that Boteler 'did not do the utmost' to save his ship and was dismissed from the service. ${ }^{26}$

What this incident shows was the necessity of having ready-to-use ammunition to hand as soon as a ship left port. But how representative were the figures stated above? Some of the records of Alexander Baxter, gunner of Namur (90) at the Battle of Cape St Vincent, survive. In his notebook, he states that on 1 February 1797, the amount of powder filled was 15 rounds for each of the 32-pounders, 18-pounders and 12-pounders. ${ }^{27}$ According to Rivers's notebook in 1809, Victory had 18 rounds filled for her 32- and 18-pounders, 20 for her 12-pounders and 25 for her 32pounder carronades. ${ }^{28}$ Captain Cumby of Hyperion (74) expected 30 rounds to be constantly filled..$^{29}$ It appears, then, that in the number of rounds filled, captains liked to have approximately one hour's worth of ammunition ready to use.

Filling cartridges as soon as the ship put to sea was not the only job that the gunner had to perform. A number of captain's standing orders remain detailing all the work that the gunner was expected to fulfil. Captain Cumby expected his gunner to examine 'the guns, carriages and furniture, reporting any defects he may discover'. During bad weather, he was to double-bank and secure the guns; he was to 'frequently examine the magazine and cause the powder to be turned every six weeks ${ }^{\text {' }}{ }^{30} \mathrm{He}$ was not in charge of the keys for his magazine or store room. These were:

to be kept in the first Lieutenant's cabin (those of the magazines to be kept in a place known by, and accessible to, the Lieutenants alone). ${ }^{31}$

On board Pegasus (28) in 1786-8 the keys were also to be 'returned to the commanding officer every night when in port, but to the officer of the watch at sea'..$^{32}$ Captain Fyffe of Indefatigable (44) issued similar instructions in $1812 .{ }^{33}$ The gunner was also to keep a 'sufficiency of wads and spare breeching constantly at hand, and to be careful that the matches, sponges etc., are kept always perfectly dry and in good order'. Everything was also to be kept 'in constant readiness for action' ${ }^{34}$

Captain Riou's (Amazon, 36) orders were similar to Cumby's. He was to keep his stores 'neat in their appointed place, and fit for action'; he was responsible 'for all the work done' by his crew; additionally, the gunner had to look after the magazine and the captain:

may always take it for granted if he receives no report to the contrary, that so essential an article as the powder is in the highest state of perfection. ${ }^{35}$ 
The gunner had a crew to help him with these tasks. These men needed to be responsible. The quarter bill of Goliath (74) demonstrates this. Of the 13 men who were stationed at the guns, nine of them were gun captains (the seaman in charge of each gun). Of the remaining crew, his mate and four men were stationed in the fore magazine. ${ }^{36}$ Somewhat intriguingly, the gunner himself is not on the quarter bill and neither he, nor any of his crew, is listed in the aft/main magazine. This is presumably where he would have been, supervising and assisting in filling cartridges. The fact that the majority of his crew were gun captains shows that not only were these men deemed responsible but they were also the more experienced men on board the ship. In his Observations and Instructions, John Davie wrote:

The gunner's crew in a ship appears to be a class much neglected. For instead of making them skilful artillerymen, and retaining them principally for that service, they are too often suffered to remain totally ignorant of it, and only perform that part of the duty of seamen which is attended to their station.

He goes on to write that as gunners they should be 'acquainted with some part of the art of gunnery'. ${ }^{37}$ The obvious implication from this is that the gunner's crew were not acquainted with the art of gunnery. The fact that nine of the 13 were gun captains on Goliath may go some way to refute this but their actual knowledge of the science of gunnery is of course impossible to gather from the quarter bills. In addition, Michael Duffy has argued that actual gunnery practice was not as common an occurrence as has previously been believed..$^{38}$

The probable experience of these men is also shown from an analysis of the Trafalgar Roll. Since its publication on CD-ROM it has been much easier to manipulate the data and draw conclusions. Unfortunately, only one member of the gunner's crew from any of the ships is listed as such so no analysis can be made of this category. However, 72 men are listed as gunner's mates. These make for interesting analysis. Table 2 below shows the ages of the gunners' mates at Trafalgar compared to those of the able seamen on four ships of the fleet.

Table 2: Age comparison of gunner's mates and able seamen of a selection of British ships at Trafalgar, 1805.

\begin{tabular}{llllllll}
\multicolumn{7}{l}{ Percentage in each age group } \\
Ship/gunner's mates & 10 to 19 & 20 to 29 & 30 to 39 & 40 to 49 & 50 to 59 & $60+$ & Unknown \\
Mates & 0 & 25 & 48.6 & 20.8 & 5.6 & 0 & 0 \\
Belleisle & 0 & 39.8 & 45.9 & 10.5 & 2 & 0.9 & 0.9 \\
Orion & 0.1 & 47.1 & 35.7 & 12.9 & 4.2 & 0 & 0 \\
Africa & 0 & 73.3 & 20.6 & 3.8 & 2.2 & 0 & 0.1 \\
Tonnant & 0 & 53.2 & 37.9 & 8.9 & 0 & 0 & 0 \\
\hline
\end{tabular}

Source: The Ayshford Complete Trafalgar Roll CD, (Brussels, 2007).

This table shows that 75 per cent of the mates were over thirty years of age. This is substantially greater than any of the figures for the individual ships. The percentage over forty years old is also far superior. There is a number of possible explanations for this. The older men may not have been physically capable of carrying on all the work needed from an able seaman. Second, the older men would have been more 
trustworthy, or more experienced at playing the system and, thus gaining promotion, than the younger seamen. They would have proved their dedication to the service and would have been less likely to make mistakes with stores as explosive as gunpowder and also less likely to desert.

Unfortunately, the only extensive records remaining are those of William Rivers; although another gunner, William Richardson, did publish his memoirs. ${ }^{39}$ Richardson, at least, seems to have been an educated man, having been at boarding school before joining the navy. ${ }^{40}$ Rivers's notebook contains pages on the process and manufacture of gunpowder along with its testing post-production. ${ }^{41}$ Without other examples it is impossible to know how common this type of dedication to the job was, especially as Rivers records have probably survived solely because he was the gunner of Victory at Trafalgar.

The gunner also had to keep account of every ordnance store that was expended. Articles were expended far more regularly than it might first be imagined. We are again fortunate that some of Rivers's, and to a lesser extent Baxter's, accounts survive.

Baxter's notebook has records of the expenditure of powder from Namur between December 1796 and June 1798 (Table 3).

Table 3: Gunpowder expended, received and remaining onboard HMS Namur, December 1796-June 1798.

\begin{tabular}{llllllllll} 
& \multicolumn{3}{c}{ First Charge } & \multicolumn{3}{c}{ Supply } & \multicolumn{2}{c}{ Talle [sic] } & \multicolumn{2}{c}{ Expence [sic] Remaining } \\
When & B & lb & B & lb & B & lb & B & lb & lb \\
December 1796 & 446.2 & 40142 & - & - & - & - & - & - & 40102 \\
January 1797 & - & - & - & - & - & - & - & - & 40102 \\
February & - & - & - & - & - & - & 90 & 8190 & 31912 \\
March & - & - & 90 & 8190 & - & 40102 & 2.72 & 252 & 39850 \\
April & - & - & - & - & - & - & - & - & 39850 \\
May & - & - & - & - & - & - & 9.43 & 853 & 38997 \\
June & - & - & - & - & - & - & 2 & 180 & 38817 \\
July & - & - & - & - & - & - & - & 81 & 38736 \\
August & - & - & - & - & - & - & - & 40.5 & 38675.5 \\
September & - & - & - & - & - & - & 2 & 180 & 38495.5 \\
October & - & - & - & - & - & - & - & 50.5 & 38440 \\
November & - & - & - & - & - & - & - & 45 & 38395 \\
December & - & - & - & - & - & - & 1 & 90 & 38305 \\
January 1798 & - & - & - & - & - & - & - & 45 & 38260 \\
February & - & - & - & - & - & - & - & 45 & 38215 \\
March & - & - & - & - & - & - & 8.5 & 725 & 37490 \\
April & - & 37490 & - & - & - & - & - & 48 & 37442 \\
May & - & - & - & - & - & - & 1.57 & 147 & 37391 \\
June & - & - & - & - & - & - & 1.87 & 170 & 37244 \\
\hline
\end{tabular}

Source: NA C 108/21. Gunner Baxter's notebook with accounts for shot and powder.

The action of Cape St Vincent can clearly be seen in February 1797 but the consistent expenditure is also equally apparent. This would have been in firing salutes or bringing ships to, etc. Rivers is more detailed in his notebook. He gives the amounts of powder expended in salutes, practice, scaling, etc. and also mentions other stores. ${ }^{42}$ 
Some evidence has been discovered that supports the view in the pamphlet Neptune and Mars that fraud was taking place. Most damning is an undated report from the Board of Admiralty (which has to have been between 1797 and 1800, because the signatories are Gambier, Wallace and Young - three Lords of the Admiralty at this time). In it is the warning that gunners are expending less powder than they are claiming to by not firing full charges in salutes. Captains are warned to be on their guard for this in the future. ${ }^{43}$ It implies that it was a regular occurrence as it had reached the level of board officers. There is some supporting evidence for the worries of the Admiralty. In the Admiralty 'black books' a list remains of warrant officers who were 'black listed' and the reasons for this. A number of the gunners in these books were listed for embezzling stores. In 1799 Christopher Atkinson, gunner of Waakzaameid (20), was sent to prison for twelve months for 'destroying and embezzling the stores committed to his charge'." Charles Benoist, gunner of Unicorn (32), had also been accused in $1797 .{ }^{45}$ Other examples are also evident.

The problem seems to have been under control by 1810 as will be shown in the evidence that James Barnouin, chief clerk in the Office of the Clerk of the Ordnance, gave to the Commissioners of Military Enquiry discussed later.

\section{SURVEYS AND REMAINS}

The main reason for the gunner keeping track of the stores expended (apart from the fact that they did not want to run short) was that he had to pass his accounts at the end of every commission. In order for his accounts to be passed the actual stores remaining had to tally with the theoretical ones in his account book. It is instructive to look at the details of how the gunner's accounts were passed and exactly what he had to submit.

Remains were taken at regular intervals to check that the gunner was doing his job properly and not embezzling government property. However, on occasions they were not taken as regularly as they should have been. Rivers states in one instance that:

the time having elapsed for Passing my Annual Account as gunner under your Command. You will be pleased to apply for an Order for a survey to enable me to pass my account. ${ }^{46}$

The same had happened on Belleisle (74) in 1804 except that in this instance the time had elapsed not only for the gunner but also the boatswain and the carpenter. ${ }^{47}$ It is interesting that in both these cases the notes refer to 'annual accounts'. In the evidence of Barnouin below it is apparent that accounts were not sent in on regular occasions. However, according to the Regulations and Instructions, the gunner was to

make an abstract of his Accounts of Receipts, Issues, and Remains, Half Yearly . . . at Midsummer and Christmas [italics in original], and to deliver the same signed to the captain, who is to audit the Said Accounts, and to Send them up certified ... to the Office of Ordnance. ${ }^{48}$

The discrepancy is intriguing. Barnouin had served in the Clerk of the Ordnance's department for thirty-one years. As such it cannot be through any ignorance on his part. What is clear is the fact that when ships were decommissioned gunners' accounts were definitely sent to London. 


\section{DECOMMISSIONING}

When ships came into port to be refitted or decommissioned they had to return all of their stores to the dockyard or gunwharf. Article 30 of Regulations and Instructions states that:

when the Ship comes into Port to be refitted or laid up, he is to apply timely to the Officer of the Ordnance at the Port to have her cleared of her Powder, Guns, and other ordnance Stores. ${ }^{49}$

It is interesting that the gunner was expected to apply to the 'Officer of the Ordnance.' This shows, in addition to everything above, the responsibility that the gunner had. As ordnance stores, especially powder, were the first stores to be removed from a ship when she returned to port, if the gunner had been lax in his application, the whole paying off of the ship would have been delayed. Ordnance stores were removed first, predominantly for safety reasons; it would not have been prudent to have fully equipped warships lying at anchor in close proximity to each other, in case one of them caught fire and exploded.

According to Rivers, the first thing that the gunner had to do when decommissioning was to empty all the made-up cartridges and return the powder to the spare barrels. All the guns were to be drawn except for three or four which were to wait until the ship was in harbour, 'in case of wanting assistance'. Portsmouth seems to have been different from the other out-ports regarding where stores were returned. Rivers wrote: 'Powder, Hides, Empty Barrels goes to magazine Portsmouth and Ball Cartridges, I believe at all other Ports except Portsmouth.' For some reason ball cartridges were returned to the gun wharf at Portsmouth. There seems to be no explanation as to why Portsmouth was unique in this matter.

Once all the powder was off the ship the gunner was to sweep the magazines 'very clean'. This was to be repeated 'for 3 or 4 day [sic] for the Dust will settle'. Once this was done 'there [was] an officer from the magazine to examining, when the powder is out'. This was presumably to make sure that the ship was safe either to place into dock or to be placed in ordinary. Rivers also advises gunners to 'tye all your stores up you can'. Again this would have been to aid his accounting. Finally, he states that 'you will gett [sic] your survey sooner. [sic] If you give your Remain to the foreman'. ${ }^{50}$

In returning stores the gunner was to see that:

the Carriages and other stores be not heedlessly flung down by the Seamen into the Vessels appointed to receive them, but lowered carefully; and when he shall find it otherwise, to acquaint the Captain. ${ }^{51}$

The seamen found to be mistreating the stores were presumably punished in some way, but so far no evidence of this has been found.

\section{ACCOUNTS}

In late November 1791, Gibbs Crawford, the Clerk of the Ordnance, wrote to the treasurer of the navy informing him that the gunner of Duke (98) had submitted his accounts for the period 28 May to 25 August..$^{52}$ As has been stated throughout this article every piece of equipment that came into the gunner's care needed to be accounted for. Additionally, receipts, indents and surveys needed to be made and kept.

The gunner did not only have to make out one account for the Board of Ordnance. Rivers explains that: 
you must apply to the Captain for Survey before you send your account. You must gitt [sic] four abstract [s] made out of your Remains; one is for the Admiral, one for the Captain, two for your self. One to go with your Accounts. The other to keep by you as your first charge. ${ }^{53}$

These accounts were not only one book. The gunner had to send his expense book, his supply and return book, all his indents and receipts, and the remain on the survey..$^{54}$ All of these were handwritten notes, some in more formal tables as exemplified by Table 3 and some, particularly the receipts, more informal and quickly written. The accounts were to be sent to the Board of Ordnance in a small packet and addressed to them. The gunner's agent was to be apprised of the same..$^{55}$ Although Rivers says to address the parcel to the Board of Ordnance, it was the Clerk of the Ordnance's department that had to examine them. According to the evidence given by Barnouin the vouchers transmitted with these accounts were the:

Primary Voucher for stores issued to him, and of vouchers for incidental supplies . . constituting together his charge; Vouchers of Stores returned by him; a Book of Expenditures; and a Voucher of the Stores remaining at the period of closing his accounts. ${ }^{56}$

This would agree with the notes made by Rivers.

Barnouin also adds some details not provided by Rivers. When asked when the gunners' accounts were transmitted to his office, he replied that 'there is no regulated period' ${ }^{57}$ He continued that 'it depends on the gunners themselves to produce their Accounts which they generally do when a Ship comes into port'. This meant that 'the Account generally contains a period of from six months to two or three years'. ${ }^{58}$ Barnouin added that there were no means of forcing the gunners to submit their accounts, except for the fact that they did not get paid unless the accounts had been passed..$^{59}$ Unless the gunner had an external source of income then this would have been incentive enough to submit the accounts quickly. Once the accounts had been passed a certificate was issued to the gunner, signed by three Board officers and addressed to the Navy Office. This would then enable him to be paid. ${ }^{60}$

On the last page of the expense book the gunner had to state that those stores that were marked as lost had been lost and 'not sold, nor embezzled, or any otherwise disposed, by or with, the knowledge ... of the said deformant' ${ }^{61}$

Rivers also has a note entitled 'Sure Guide, to Pass your account before you send them away'. ${ }^{62} \mathrm{He}$ advises gunners to sum their first charge, i.e. what they received when the account was opened, and their additional supplies. Then he says to sum all the expense together, and next sum the returns; once the gunner has added his returns to his expenses, he is to subtract them from the total supplied. This will then give the 'true remain'. He concludes that this final number should agree with the gunner's working abstract. If it does not, Rivers's advice is obvious and not particularly helpful: 'What don't agree examing [sic] again'. ${ }^{63}$

\section{CONCLUSION}

Without a more detailed study, N.A.M Rodger's assertion that gunners were almost always former 'petty officers and common seamen' is impossible to judge for the period discussed in this article. What is clear is that through the examination process the navy guaranteed that its gunners were all able to reach the minimum standard of literacy and numeracy required to fulfil the tasks that were required of them and in 
this way a parallel can be seen with the lieutenants' exam where the navy guaranteed that its officers could fulfil their duties.

The charge of embezzlement alluded to in the pamphlet Neptune and Mars also seems to have been to a large extent brought under control. When the Commissioners of Military Enquiry asked Barnouin whether there had been many irregularities in the accounts, he answered 'very few' ${ }^{64}$ One way the Board of Ordnance (and navy) checked that the gunners were not defrauding the nation was to have fixed annual surveys made of the gunners' stores. These could then be checked against the working abstracts that the gunner of the surveyed ship would have carried. If these were grossly different, then fraud would have been suspected. It is also noticeable that gunners were allowed to survey each other. If there had been a fear of endemic fraud, then this would have been foolhardy. On home stations, Board of Ordnance personnel would have been able to survey the gunners, but on foreign stations these personnel would not have been available so it may have been necessity to get gunners to survey each other.

The duties of the gunner have been shown to be many and varied. They had charge of, arguably, the most important (certainly the most hazardous) stores on board a warship. Each of these had to be accounted for. Rivers does provide evidence for ways to cheat the system. He advises gunners to have as many wads as possible as part of their junk. This would have made it easier to pass the accounts. However, the fact that Rivers felt he could write this down shows that it was an accepted trick of the trade. If it had been frowned upon it is unlikely that he would have done so.

Finally, captains also had to have a level of trust in their gunners, if for no other reason than they did not receive their pay unless gunners' accounts were passed. This said, as with all of the standing officers, gunners were not allowed to have the keys to their own magazines or store cupboards. These were always kept with the captain or in the first lieutenant's cabin.

Although their independence was limited in many ways, it was for obvious reasons. They had to ask permission to fill powder. Any commanding officer would want to have control over this procedure. The powder was the single most dangerous article on board a warship. One mistake and the ship could be lost. The fact that the keys for the magazine were kept by the commissioned officers is again an obvious safeguard. The officers' cabins were more secure. It would also guard against ammunition being seized in the event of a mutiny.

A discussion on gunners also adds some elements to the fighting ability of British warships. The available evidence suggests that it was not uncommon for captains to have enough cartridges filled for approximately an hour's fighting as soon as their vessel left port. This was particularly necessary in time of war. It also helps to explain why British warships were always ready for combat. With the possible exception of Ardent - and even here the gunner seemed happy that enough cartridges were available for combat - no examples have been discovered of British warships starting an engagement short of filled cartridges.

This article has argued that gunners were an important cog in the operations of Royal Navy warships during the period discussed. Barnouin's evidence suggests that fraud levels by 1810 were at a low level and the examination process guaranteed that all gunners were literate and numerate enough to fulfil the jobs demanded of them. 


\section{References}

1 I am grateful for the comments of the Hon. Editor and two anonymous referees.

2 N.A.M. Rodger, The Wooden World: An Anatomy of the Georgian Navy (London, 1988), 22.

3 N.A.M. Rodger, The Command of the Ocean (London, 2004), 393.

4 Anon., Advice to the Officers of the British Navy (London, 1785), 112.

5 Ibid.

6 Anon., Neptune and Mars: or the fleet and army display'd in their true colours. Containing their characters... In two parts. (London, 1779), 51-2.

7 Regulations and Instructions relating to His Majesty's service at sea. Established by His Majesty in Council (13th Edition, 1790), 110-11. This article read the same from 1731.

8 NA ADM 11/39. John Brockinan, 17 March 1807.

9 See for instance, Wellcome Library, London (hereafter WL), MS 3677. Certificate of George Jones or NA C 108/21; and NA ADM 6/127.

10 NA ADM 6/127.

11 The only account books that have been uncovered are those of William Rivers and Alexander Baxter (both used throughout this article and these only represent one or two commissions). When one considers that every gunner on each commission would have had to keep one then this is a very low level of archival survival.

12 Rivers's notebook is the only complete one that has so far been uncovered in the archives.

13 Royal Naval Museum, Portsmouth (Hereafter RNM) 1998.4.1 'Gunnery notebook, 1793-1812', 41.

14 Ibid., 39.

15 Ibid., 39-41.

16 RNM 1998.41.1, 41.

17 Minutes of the Proceedings at a CourtMartial Assembled to Enquire into the Cause of the Loss of His Majesty's late Ship Ardent (London, 1780), 3-4.

18 Ibid., 13.

19 Ibid., 4.

20 Ibid., 57-8.

21 Ibid., 66.
22 Regulations and Instructions, 102.

23 Proceedings at a Court-Martial, 66. Wads were easier and quicker to make up than powder cartridges thus explaining the lower number.

24 Ibid., 4.

25 R.J.B. Knight, The Pursuit of Victory. The Life and Achievement of Horatio Nelson (London, 2006), 226.

26 Proceedings at a Court-Martial, 90.

27 NA C 108/21. Records of Gunner Alexander Baxter.

28 RNM 1998.41.1, 86.

29 H.G. Thursfield, ed., Five Naval Journals, 1789-1817 (NRS, 1951). Orders and Regulations for the Government and good discipline of HMS Hyperion, 343.

30 Ibid.

31 Ibid., 333.

32 Brian Lavery, ed., Shipboard Life and

Organisation, 1731-1815 (NRS, 1998)

Captain's Orders, HMS Pegasus, 1786-8, 94.

33 Ibid. Captain's Orders, HMS

Indefatigable, 1812, 191.

34 Thursfield, Five Naval Journals, Orders

and Regulations ... of HMS Hyperion, 344.

35 Lavery, Shipboard Life and Organisation, Captain's Orders, HMS Amazon, 1799, 131.

36 Lavery, Shipboard Life and Organisation, Quarter Bill, HMS Goliath, 1805, 276-87.

37 Ibid. Extracts from 'Observations and Instructions’ by John Davie, 1804, 265.

38 M. Duffy, 'The Gunnery at Trafalgar: training, tactics or temperament?', Journal for Maritime Research (August 2005). Accessed 20 January 2009. www.jmr.nmm.ac.uk/server/ show/ConJmrArticle.201 Particularly pages 2-3 on British gunnery training.

39 S. Childers ed., A Mariner of England (London, 1970, new impression).

40 Ibid. 2.

41 RNM 1998.41.1, 116-21,

42 RNM 1998.41.1 'An account of the Expence of Ordnance Stores Onboard of His Majesty's Ship Victory Peter Dumerasq Esq Commander. 31 January 1809 to [28 February, but not complete]', 129-31. 
43 National Maritime Museum, Thirteenth Report (Master-General and Board Greenwich, (Hereafter NMM), NMM KEI/ of Ordnance). (BPP, 1810-11, IV) Appendix 45/2. Undated Order in Council.

44 NA ADM 11/39. Christopher Atkinson, 29 May 1799.

45 Ibid. Charles Benoist, 8 August 1797.

46 RNM 1998.41.1, 46.

47 WL, MS.3668. Belleisle, 1 May 1804.

48 Regulations and Instructions, 108.

49 Regulations and Instructions, 109.

50 RNM 1998.41.1 Gunnery notebook, 47.

51 Regulations and Instructions, 110.

52 NMM BRA 128/6. Crawford to Treasurer of the Navy, 26 November 1791.

53 RNM, 1998.41.1, 35.

54 Ibid. Unfortunately no complete set of accounts has been discovered.

55 Ibid.

56 Commissioners of Military Enquiry: no. $18,178$.

57 Ibid.

58 Ibid.

59 Ibid..

60 Ibid.

61 RNM 1998.41.1, 37.

62 Ibid., 42.

63 Ibid., 42.

64 Thirteenth Report. Appendix no. 18, 178.

Dr Gareth Cole has recently completed a $\mathrm{PhD}$ thesis entitled 'The Office of Ordnance and the Arming of the Fleet in the French Revolutionary and Napoleonic Wars, 1793-1815', at the University of Exeter. $\mathrm{He}$ is currently working in the library at Exeter and is the web editor for the SNR. 